\title{
A.3.
}

\section{How I Became a New Cinema Historian}

\section{Melvyn Stokes}

In 1995-6 I taught for the first time an MA course in film history. It was called Hollywood and the history of American popular film. The first term theme was "American History and Hollywood Film"; the second term it was "Hollywood Genres." The course was built around the screening and discussion of relevant film texts. But every week I also included reading for an additional topic. All this may seem of picayune interest, of no significance to others than myself and - maybe - the 15 students who took the course. But new courses at my institution, University College London (UCL), have to be vetted for their academic and intellectual content. I thought this process might be easier if I included some theory - and spectatorship theory seemed just the thing, the hottest topic at the time in film studies. So I included lots of spectatorship theory in the first few weeks of the course. We began with Christian Metz's ideas on semiotics, Louis Althusser's on ideological state apparatuses, the application of Jacques Lacan's ideas on psychoanalysis to film spectatorship, and Laura Mulvey's pioneering work on the theoretical female spectator. At this point, an American MA student asked an interesting question: "Why are we looking at so much theory? We're historians."

A good question. Part of the answer is that those who founded the discipline of film studies were very largely not historians. They came from backgrounds in literary studies, philosophy, semiotics, history of art and communication studies. Their principal focus was on the film as text. By the late 1960s and 1970s, this interest in the filmic text had also spawned growing interest in spectatorship - but the spectators involved were only theoretical ones instead of flesh-and-blood audience members. They had become important initially as a 
consequence of a broad reappraisal of politics and society in France that accompanied - but was far from being confined to - les événements of May 1968. French writers on film endeavoured to demonstrate how the cinematic text (and thus cinema itself as an institution) conditioned or "interpellated" (Althusser, 1971) spectators to acquiesce in and preserve dominant ideological formations (and thus existing social, economic and political norms). They at first utilised approaches that were grounded in Saussurean semiotics (Metz, 1974) and, later, Lacanian psychoanalysis (Metz, 1982). In the 1970s, as these ideas and approaches gained ground in the rapidly-expanding field of field studies, they were accompanied by a growing interest - symbolised by the publication of Laura Mulvey's article "Visual Pleasure and Narrative Cinema" in British film journal Screen - in theoretical female spectatorship (Mulvey, 1975).

As film studies practitioners became ever more intense in their pursuit of elusive (and usually passive) theoretical spectators, the most exciting work in history itself - from the Annales school in France through the work of British social and cultural historians such as E. P. Thompson and Raymond Williams to the pioneers of women's and labour history in the US - was going in exactly the opposite direction. The main preoccupation of these scholars was with rediscovering and documenting the lives of ordinary men and women and, wherever possible, demonstrating how they actively fought for control over their lives and circumstances. They did their work, in common with more conventional historians, in the empirical fashion that, at least since the work of German historian Leopold von Ranke in the nineteenth century (Boldt, 2015; Iggers and Powell, 1990), has revolved around the examination and analysis of archival materials. This distinguished them sharply both from theorists of film spectatorship (most of whom were preoccupied with spectatorship for Hollywood films) and the much longer effort - stretching over nearly half a century - to 
write the history of the American movie industry, since the First World War the economically dominant film industry across much of the world.

The first two major "histories" of American film were published by Terry Ramsaye in 1926 and Benjamin Hampton in 1931. Both were produced by men who had worked in the industry; each was from a dramatically different perspective. Ramsaye's A Million and One Nights reflected his background as an engineer, journalist and movie editor/producer. Impressionistic and anecdotal, it centred on the film industry's business and technological giants (particularly Thomas A. Edison) and largely ignored aesthetic, social, and economic issues. Hampton also had a journalistic background, but he had been forced by business pressures to sell his crusading muckraking magazine, Hampton's, and also proved unsuccessful as a producer in the movie business. His A History of the Movies was primarily a critique of corporatisation in Hollywood as a threat to the democratic process. He wrote about films only as commodities and focused on issues such as the defeat of the Edison "Trust" and the emergence of chains of movie theatres. Lewis Jacobs, the author of The Rise of the American Film (1939), the next general history of American movies, was even more politically committed than Hampton: he defended the right of films to address social issues and be made without too much interference. But his attempt to analyse the main elements of the movie industry across the stages of its growth was often little more than a description of the films he deemed "significant." Two other surveys of the history of American film were published in the 1950s: Arthur Knight's The Liveliest Art (Knight, 1957) and Richard Griffith and Arthur Mayer's The Movies (Griffith \& Mayer, 1957). Neither was a scholarly work: Mayer was a former theatre manager and studio publicist who had authored an entertaining if unreliable memoir of life inside the movie industry of the 1930s and 1940s (Mayer, 1953). It was not until the 1960s that the first significant film histories by academics began to appear: Albert R. Fulton's Motion Pictures: The Development of an Art (Fulton, 1960) and Kenneth 
Macgowan's Behind the Screen (Macgowan, 1965). In 1971, professor of English Gerald Mast published the first of a new generation of general histories, A Short History of the Movies (Mast, 1971). Yet in common with its predecessors and immediate successors, this depended heavily on anecdotal evidence and its account of movie history focused principally on the activity of a succession of "great" men.

I spent most of the summer of 1974 researching the lives of American reformers before the First World War at the Wisconsin State Historical Society Archives in Madison. There I was introduced to a Professor of Communications, Tino Balio, who was just about to leave for a semester's sabbatical in London. Balio told me he had been working in the archives of the United Artists studio and was going to carry on looking at United Artists files in London. To my shame, looking back, I had no idea how novel what he was doing was. Didn't all historians look at archives? But before the 1970s, almost no-one in film studies seemed aware that there were archival materials available for the study of film. This made the publication of Balio's history of the United Artists studio (Balio, 1976) a ground-breaking event: it abandoned the "great men" approach to the history of the movies by analysing United Artists as an economic institution and it was grounded in thorough research in the studio archives. In the decade leading up to the start of my MA course on film history, film scholars began increasingly to use archival research to shed light on the diverse contexts that influenced the making and form of film texts. In 1988, for example, Thomas Schatz (Schatz 1988) discussed the effect of the different studios' house style on the movies they produced in The Genius of the System. In 1991, Lea Jacobs analysed Production Code files to demonstrate that the narrative content of films was often greatly influenced by Hollywood's system of self-regulation. Looking at "fallen women" films of the 1930s and early 1940s, she argued that much of what was shown in them was the product of a process of constant negotiation (Jacobs, 1991). 
There were other books and articles over this period - works I was myself reading or becoming aware of. But my initial interest was in how American history had been represented and interpreted in Hollywood films and I taught an undergraduate one-term course on this from 1989. And it was through teaching American history, as well as my growing interest in film and its uses, that I found myself setting off on a new path that would engage me for much of the next decade.

UCL has had since 1930 a tradition of lectures in American history endowed by the Commonwealth Fund. Once a series of lectures by a distinguished US historian, this had been changed in the mid-1960s into a single lecture followed by a day's colloquium discussing the lecture. This formula in turn was looking somewhat tired by the beginning of the 1990s. I pushed for a new style of larger conference with keynote speakers and paper submissions. By 1996, I had organised several of these, including events exploring race and class in the American South since 1890 (1992), the "market revolution" in nineteenth-century America (1994) and the US and the European Alliance (1996). Co-edited books based on these conferences had either been published or were in preparation. I thought it was finally about time to have a conference in 1998 on what was increasingly my new specialty of film. The subject of this conference emerged as a result of two influences. The first was my growing interest in the making and reception of D. W. Griffith's The Birth of a Nation (1915) - an interest that would eventually lead to a 2007 book on the subject. Back in the mid-1990s, however, through following The Birth of a Nation trail, I discovered Janet Staiger's fine essay on the critical debates surrounding the film in the decades after its first release (Staiger, 1992a). This, in turn, led to Staiger's broader ideas on the historical reception of movies (Staiger, 1992b). The second influence arose from a frank recognition on my part that, as a johnny-come-fairly-lately to film history, it would be sensible to seek a partner for such a conference. I knew of Richard Maltby from various British Association of American Studies 
conferences I had attended in the past. So I was very pleased to see that he was giving a seminar paper in London's Institute of Historical Research while I was mulling over the idea of a film history conference. For Richard, all unsuspecting, it was an opportunity to discuss $I$ Am a Fugitive from a Chain Gang (1932). For me, it was a kind of audition. At the end of the paper, I asked a question. I don't remember what it was, though I do remember wondering if it might be too elementary. Richard treated it with a seriousness it perhaps didn't deserve and I was impressed. A few days later, I rang him up at Sheffield Hallam University and we talked about possible topics for a film history conference. It was during this discussion that Richard observed that "not much has been done on audiences."

In the end, the call for papers we issued covered both movie reception and movie audiences. Janet Staiger agreed to give a keynote on reception and Robert C. Allen, who had published a pioneering article on nickelodeon audiences in Manhattan (Allen, 1979), on audiences. Expecting a small-scale conference, we were overwhelmed by the response to the call. Eventually, over 160 people registered and more than 50 gave papers. We divided all the papers into four streams for programming purposes. Once we'd done this, I sent off a list of the papers we'd categorised in this way to a number of mostly British publishers. Routledge, with Rebecca Barden then as commissioning editor for film, was interested and we talked about the possibility of one large book bringing together the best of the conference papers. Other publishers turned down the idea flat: Andrew Lockett, for example, then commissioning editor for film and media at Oxford University Press, wrote to me a courteous note that OUP didn't usually publish conference volumes of this kind. Academics are just as used as actors to rejection, so I thought little more of this. Then, a few weeks later, I got a telephone message in my mailbox to "please call Andrew Lockett at the BFI" and a number to ring. I did and Andrew, who had just become head of educational publishing at the British Film Institute, invited me to come to see him at Stephen Street in London. We sat in his fairly 
small office for a while making small talk and discussing the forthcoming conference. Then he produced the list of papers divided into streams I had sent, hunched over it and said quietly "I don't think this is one book [long pause]. I think it's four books." For the first (and possibly last) time in my life, I left a meeting knowing what it must feel like to win the lottery.

By the time the conference was over and we were working on the BFI volumes, Richard had moved to Flinders University in Australia. We fell into a pattern of hemispherical collaboration by email that would last nearly five years. At our most efficient, I would edit a piece received perhaps from somewhere in the U.S., send it off at the end of the European day (I was and still am an EU "Remainer") to Richard, who would open it on an Adelaide morning, edit it more and often send it back to the author that same day. In this fashion, we produced the first two volumes of our BFI series on audiences in 1999, another in 2001 and the final one in 2004 (Stokes and Maltby 1999a; Stokes and Maltby 1999b; Stokes and Maltby 2001; Maltby and Stokes 2004). In 2003, I organised a second "audiences" conference at UCL on "Hollywood and Everyday Life." Again, it was a collaboration with Richard with, this time, considerable input from Robert C. Allen. It also resulted in a book, published at Richard's suggestion by Exeter University Press (Maltby, Stokes and Allen, 2007).

Once the 2003 conference was over, apart from these publications plans, I moved on to working on other things, including a book on the making and reception of D. W. Griffith's appalling racist epic The Birth of a Nation (1915). I looked benignly on efforts to keep the spirit of '98 and '03 alive through a symposium in Virginia chaired by Arthur Knight in 2004 and a conference in Ghent organised by Daniel Biltereyst and Philippe Meers in 2007. But I did not participate in them (apart from a flying visit at the start of the Ghent conference to launch the Going to the Movies book) or in the new HoMER (History of Moviegoing, 
Exhibition and Reception) organisation founded in 2004. Those involved were fine scholars who were actually researching in depth local exhibition and audiences. I didn't think I would ever do anything of this kind myself. But then, in 2008, I was invited by the alumni office at UCL to give a lecture on films of the 1960s to a meeting of alumni who had graduated in that decade. At the end of the talk, nearly a third of the audience impressed me by gathering around the podium to talk about their experiences of cinema-going in London in the 1960s. It occurred to me afterwards that it might be a good idea to collect memories of this kind, not just from graduates but from the wider population and not simply from London but the UK as a whole.

In academic life, there is often a long gap between having an idea and attempting to put it into execution. It was not until 2011 and 2012 that I finally put together an application to the Arts and Humanities Research Council (AHRC) in Britain for a 3-year research project to be called Cultural Memory and British Cinema-going of the 1960s. Between 1 January 2013 and 31 December 2015, with the participation of three brilliant successive research associates, Matthew Jones, Emma Pett and Patrick Glen, we collected over 900 completed questionnaires on people's memories of cinema-going and did over 70 interviews. In the last four months of the project, Patrick Glen and Matt Mahon, Digital Curation Manager in UCL Library, worked together to turn the project records into a digital collection. In late 2016, thinking that the results of the earlier project - and the existence of our new collection might perhaps be publicised more widely, I successfully applied to the AHRC for a further year's funding (1 May 2017-30 April 2018) for impact and engagement, having as its centrepiece 44 events of different kinds across the UK designed to bring our findings to a broader audience.

During the years in which I was working on these two projects, HoMER was taking off as an organisation. Collaborating in some years with the European Network for Cinema 
and Media Studies (NECS), an association of film scholars and archivists, it organised a series of workshops with growing numbers of panels and speakers. I saw the first of these, in Prague in June 2013, advertised as a sequel to the Ghent conference of 2007. Since it included participants working on oral and written memories of cinema-going, I asked Matthew Jones, then researcher on the Cultural Memory and British Cinema-going project, to attend and talk about the work we were doing. Matt came back full of enthusiasm for the scholars HoMER had attracted and the research they were engaged upon - in many respects analogous to our own. The following year, I attended the HoMER workshop at the NECS conference in Milan, where Philippe Meers was kind enough at the opening meeting to greet me as one of the founders of the study of audiences and exhibition. I also went to the conference organised by HoMER in association with the AHRC Early Cinema in Scotland project in Glasgow in June 2015 and the HoMER workshop at NECS in Potsdam in June 2016.

In the very first of the British Film Institute series Richard and I edited, it was noted in the introduction that

The history of the audience remains the most elusive aspect of cinema history, since audiences form only the most temporary of communities, and leave few traces of their presence. But the historical significance of film (as of most of popular culture) is to be found more in its reception than its production - in the meanings, often not clearly articulated, that audiences read into it and the uses to which they put it. (Stokes and Maltby 1999b: 9)

The audiences for American movies that our contributors dealt with in this first volume were all themselves American. In the second volume, a number of scholars began to explore the 
reactions of foreign audiences to American films: Annette Kuhn, for example, used material from her extensive survey of British cinema-going of the 1930s to write about a small group of British women from Lancashire who - by regularly watching video cassettes of the musicals of Nelson Eddy and Jeanette MacDonald - remained fans of the stars and their films sixty years later (Kuhn 1999). In the final volume of the series, contributors looked exclusively at foreign audiences - in Australia, Belgium, Central Africa, France, India, Japan Turkey and the UK - for American films, analysing how these local audiences had understood and sometimes reimagined such movies from the perspective of their own cultural identities (Maltby and Stokes 2004). In the book we edited with Robert C. Allen in 2007, most of the chapters dealt with American audiences and exhibition, though the final part of the book included a number of studies of how foreign audiences exhibited and received American productions (Maltby, Stokes and Allen, 2007).

By 2011, when Richard Maltby, Daniel Biltereyst and Philippe Meers edited a volume entitled Explorations in New Cinema History arising out of the Ghent conference in 2007 (Maltby, Biltereyst and Meers, 2011), it was clear that audience studies of cinema were changing. While American audiences and reception remained an object of study, there was a movement away from the focus on the screening of what could be termed "Hollywood" products towards alternative film exhibition practices. Whether in or outside the United States, there has been a growing concentration on the local and the specific, as opposed to the national (or international) and the general. Much of the work of new cinema historians has been on "microhistory" - detailed studies of local patterns of distribution, exhibition and cinema-going that map them into analysable datasets using techniques such as "spatial analysis and geovisualisation" (Maltby, 2011b: 9). Yet new cinema history has also endeavoured to bring together both quantitative history and qualitative history, including ethnographic techniques and oral history as well as more traditional archival work in 
newspapers, the cinema "trade" press, and the records of those engaged in the businesses of distributing and exhibiting movies. Its aim is an ambitious one: to create a social and cultural history of cinema-going that has broad appeal across a range of disciplines. By its very nature indeed, as Maltby points out in an introduction that is simultaneously an intellectual tour de force and a manifesto, new cinema history is "inherently interdisciplinary" (Maltby, 2011b: $34)$.

In less than 20 years, I have gone from being a historian of the ideas of pre-World War I American reformers to directing two research projects on 1960s British cinema-going. Without my growing interest in movie exhibition, audiences and reception, this would never have happened. So I am happy to define myself today as both a supporter and practitioner of what is now the new cinema history.

\section{References}

Allen, R. C. (1979) “Motion Picture Exhibition in Manhattan, 1906-1912: Beyond the Nickelodeon,” Cinema Journal, 18 (2), pp. 2-15.

Althusser, L. (1971) "Ideology and ideological state apparatuses (Notes Towards an Investigation)," in Lenin and Philosophy, trans. Ben Brewster, London: New Left Books), pp. 127-86.

Balio, T. (1976) United Artists: The Studio Built by the Stars. Madison, WI.: University of Wisconsin Press.

Boldt, A. D. (2015) The Life and Work of the German Historian Leopold von Ranke (17951886): An Assessment of His Achievements. Lewiston, New York: Edwin Mellen Press. Fulton, A. R. (1960) Motion Pictures: The Development of an Art from Silent Films to the Age of Television. Norman: University of Oklahoma Press. 
Griffith, R. and Mayer, A. (1957) The Movies: The Sixty-Year Story of the World of Hollywood and Its Effect on America: From Pre-Nickelodeon Days to the Present. New York: Simon and Schuster.

Hampton, B. B. (1931) A History of the Movies. New York: Covici, Friede.

Iggers, G. and Powell, J. M. (eds.) (1990) Leopold von Ranke and the Shaping of the Historical Discipline. Syracuse, New York: Syracuse University Press.

Knight, A. (1957) The Liveliest Art: A Panoramic History of the Movies. New York: Macmillan.

Jacobs, L. (1991) The Wages of Sin: Censorship and the Fallen Woman Film, 1928-1942. Madison, Wisconsin: University of Wisconsin Press.

Jacobs, L. (1939) The Rise of the American Film: A Critical History. New York: Harcourt, Brace and Co.

Kuhn, A. (1999) “"That day did last me all my life': cinema memory and enduring fandom.” In Stokes, M. and Maltby, R. (eds.) (1999b) Identifying Hollywood's Audiences: Audiences and Cultural Exchange. London: BFI Publishing (pp. 135-46).

Macgowan, K. (1965) Behind the Screen: The History and Techniques of the Motion Picture New York: Delacorte Press.

Maltby, R., Biltereyst, D. and Meers, Ph. (eds.) (2011) Explorations in New Cinema History: Approaches and Case Studies. Malden: Wiley-Blackwell.

Maltby, R., Stokes, M. and Allen, R.C. (eds.) (2007) Going to the Movies: Hollywood and the Social Experience of Cinema. Exeter: Exeter University Press.

Maltby, R. (2011b) “New Cinema Histories.” In Maltby, R., Biltereyst, D. and Meers, Ph. (eds.) Explorations in New Cinema History: Approaches and Case Studies. Malden: WileyBlackwell (pp. 3-40). 
Maltby, R. and Stokes, M. (eds.) (2004) Hollywood Abroad: Audiences and Cultural Exchange. London: BFI Publishing.

Mast, G. (1971) A Short History of the Movies. New York: Pegasus.

Mayer, A. (1953) Merely Colossal: The Story of the Movies from the Chaise Longue to the Long Chase. New York: Simon and Schuster.

Metz, C. (1974) Language and cinema. The Hague and Paris: Mouton.

Metz, C. (1982) The Imaginary Signifier: Psychoanalysis and the Cinema. Bloomington: Indiana University Press.

Mulvey, L. (1975) “Visual Pleasure and Narrative Cinema,” Screen, 16(3): 6-18.

Ramsaye, T. (1926) A Million and One Nights: A History of the Motion Picture. New York: Simon and Schuster.

Schatz, T. (1988) The Genius of the System: Hollywood Filmmaking in the Studio Era. New York: Pantheon.

Staiger, J. (1992a) “The Birth of a Nation: Reconsidering Its Reception.” In Staiger, J. Interpreting Films: Studies in the Historical Reception of American Cinema. Princeton: Princeton University Press (pp. 139-53).

Staiger, J. (1992b) Interpreting Films: Studies in the Historical Reception of American Cinema. Princeton: Princeton University Press

Stokes, M. and Maltby, R. (eds.) (1999a) American Movie Audiences: From the Turn of the Century to the Early Sound Era. London: BFI Publishing.

Stokes, M. and Maltby, R. (eds.) (1999b) Identifying Hollywood's Audiences: Cultural Identity and the Movies. London: BFI Publishing.

Stokes, M. and Maltby, R. (eds.) (2001) Hollywood Spectatorship: Changing Perceptions of Cinema Audiences. London: BFI Publishing. 